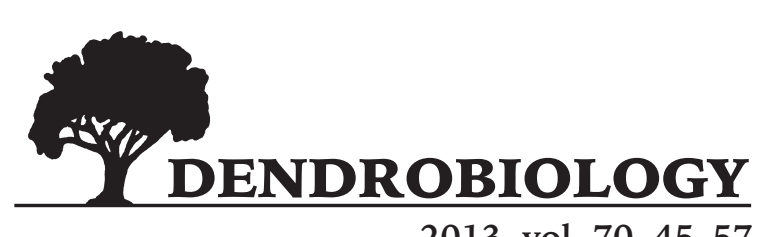

2013, vol. 70, 45-57

http://dx.doi.org/10.12657/denbio.070.005

\author{
Maria Morozowska, Barbara Gawrońska, Agata Woźnicka
}

\title{
Morphological, anatomical and genetic differentiation of Cornus mas, Cornus officinalis and their interspecific hybrid
}

Received: 11 September 2012; Accepted 19 December 2012

\begin{abstract}
Cornus mas L., C. officinalis Sieb. et Zucc. and their putative interspecific hybrid specimens were examined in order to describe their morphological, anatomical and genetic differentiation. Petiole length, number of leaf veins, pedicel and bract length, stone size, thickness of pericarp layers, the size and number of locules and the number of cavities were measured. Pedicels and bracts were shown to be significantly longer for C. mas (7.22 and $6.95 \mathrm{~mm}$ ) and for the putative hybrid $(9.11$ and $6.61 \mathrm{~mm})$ than for C. officinalis $(6.86$ and $5.81 \mathrm{~mm}$, respectively). Average values of stone width and thickness, exocarp and mesocarp thickness, the number of cavities in the endocarp obtained for the putative hybrid differed significantly in comparison to $C$. mas and were similar to C. officinalis. Genotypes of the examined species were evaluated for genetic relationships using random amplified polymorphic DNA (RAPD) markers. Initial screening of the bulks of C. mas and C. officinalis compared with their putative hybrid using 72 decamer random primers resulted in the identification of 24 primers differentiating both species and their putative hybrid and showing reliable polymorphisms. Among a total of 485 amplified fragments, $89.7 \%$ were polymorphic, $18.8 \%$ were specific to C. mas individuals, and $18.6 \%$ were specific to the individuals of $C$. officinalis. In obtained profiles of the examined hybrid individual specific products absent in the genotypes of both parents were observed. The phylogenetic tree revealed two separate clusters including $C$. mas and C. officinalis accessions, respectively. The biggest genetic distance was observed for hybrid specimens, although the hybrid belonged to the $C$. mas cluster.
\end{abstract}

Additional key words: fingerprinting, hybridization, inflorescence, leaf, RAPD, stone

Addresses: M. Morozowska, A. Woźnicka, Department of Botany, Poznań University of Life Sciences, Wojska Polskiego 71C, 60-625 Poznań, Poland, e-mail: mariamor@up.poznan.pl, B. Gawrońska, Department of Biochemistry and Biotechnology, Poznań University of Life Sciences, Dojazd 11, 60-632 Poznań, Poland

\section{Introduction}

The taxonomic, molecular, and phylogenetic relations among Cornus species have been controversial for many years (Fan and Xiang 2001). According to molecular data from both nuclear and chloroplast genomes of Cornus, the genus diverged early into two large lineages: the blue- or white-fruited group and the red-fruited group (Xiang et al. 1996; Xiang et al. 1998; Fan and Xiang 2001). Cornelian cherries (Cor- nus, subgenus Cornus s.l., including subg. Afrocrania and subg. Sinocornus), one of the two clades into which the red-fruited group separated, include six presently existing species: Cornus sessilis Torr. ex Durand (western North America), C. mas L. (Europe), C. officinalis Sieb. et Zucc. (Asia), C. chinensis Wangerin (Asia), C. volkensii Harms (Africa), and C. eydeana Q. Y. Xiang et Y. M. Shui (Asia). Diagnostic characteristics of these groups include inconspicuous inflorescence bracts, stalked flowers grouped in umbel-like clus- 
ters, and fruit stones riddled with orbicular or ovoid cavities (Eyde 1988). The four Eurasian species form a clade consisting of two sister pairs, C. mas - C. officinalis and C. chinensis - C. eydeana (Xiang et al. 1998; Fan and Xiang 2001; Xiang et al. 2005; Xiang et al. 2006). Due to their very close phylogenetic relationship hybridization might happen between these species, just as it happens presently in situ with very closely related Cornus species with overlapping distribution areas (Orton 1985; Wagner 1990). Additional examples of natural hybridization have been documented in various arboreta and botanical gardens where the opportunity for hybridization is sometimes increased when closely related species grow in close proximity (Kehne 1978). Since dogwoods are morphologically highly heterogeneous, the variability in inflorescences, fruits and leafage has formed the basis for the divisions of that genus into different numbers of subgenera or sections. The main leaf features taken into consideration while distinguishing dogwood species representing particular subgenera or sections is the number of veins found on the leaves as well as the type and the presence of hair on leaf undersurface. The inflorescence architecture, which is important to angiosperm reproduction, had been examined within last several years among different plant families (Benlloch et al. 2007). Generative plant organs such as flowers, fruits and seeds show less morphological variation in comparison with vegetative ones and because of that they are very useful in plant taxonomy, especially in distinguishing very closely related species. Cornelian cherries are the group of dogwoods bearing a determinate umbel (ciadioid) with four unexpanded, nonpetaloid, involucral bracts (Feng et al. 2011). Length, shape and size of particular flower elements may be of taxonomic significance and may differentiate species belonging to the cornelian cherries group (Seneta 1994; Xiang et al. 2003). According to recent results, stones of cornelian cherries also have some diagnostic features, which can be useful for identifying extant species and fossil materials. Structural features of stones can be used to compare relations between genera and to resolve relationships between them (Manchester et al. 2010).

Within several dozen past years different molecular biological techniques, among them analysis of DNA fingerprinting, restriction fragment length polymorphism (RFLP) for C. florida (Culpepper et al. 1991), cpDNA restriction sites (Xiang et al. 1996), $r b c \mathrm{~L}$ sequence data (Xiang et al. 1993), and nuclear 26S rDNA and 26S rDNA-matK-rbcL sequences (Fan and Xiang 2001, 2003), have been employed to further elucidate phylogenetic problems within Cornales. Microsatellite loci or simple sequence repeats (SSRs) have been employed in Cornus analyses, used to verify the movement of pollen between individual genotypes involved in controlled crosses, and used to verify the cross-pollination of C. kousa intraspecific hybrids (Wadl et al. 2009).

Polymerase chain reaction (PCR)-based techniques have been used extensively in genetic analysis and identification of molecular markers in different plants. Such methods as randomly amplified polymorphic DNA (RAPD) described by Williams et al. (1990) or inter-simple sequence repeat (ISSR) analysis developed by Zietkiewicz et al. (1994), which use single primers in PCR amplification and do not require the knowledge of flanking sequences, became very important tools for genetic study. They have wide applications for all organisms, regardless of the availability of information about their genome sequence, including different cultivars of Cornus spp. ISSR markers were used for a diversity study in groups of several commercial cultivars and new selections of dogwood (Shi et al. 2010). Ercisli et al. (2008) demonstrated in their study that RAPD analyses can be use to differentiate and classify cornelian cherry (Cornus mas L.) genotypes.

The aim of the presented work was the comparative analysis of taxonomically important morphological leaf and inflorescence characteristics, selected fruit and stone anatomy features, and the genetic structure of Cornus mas and C. officinalis using RAPD markers in order to describe their differentiation and to identify their putative interspecific hybrid.

\section{Materials and methods}

\section{Collection of plant material}

Plant material was collected in 2010-2011 from several individuals of Cornus mas, Cornus officinalis, and their probable interspecific hybrid C. mas $\times$ C. officinalis in several Polish botanical collections. Representative samples of 30 leaves, 30 inflorescences and 30 ripened fruits were collected for each species under study in July and August. For fruit anatomical studies five fruits were examined for each species under study. Fresh young leaves of five individuals of $C$. officinalis, five individuals of C. mas, and one specimen of their putative hybrid C. mas $\times$ C. officinalis were collected for genetic studies (Table 1).

\section{Morphological and anatomical analysis}

Morphological features of leaves, inflorescences and fruits, as well as anatomical characteristics of fruits and stones examined in the presented study are given in Table 2. Leaf and inflorescence measurements were taken in three and five replications, respectively. Stone width and thickness were measured at stone mid-length. Endocarp characteristics were measured across the germination valve. Analysis of the anatomical structure of the fruits and stones and their biometric measurements were performed on the 
Table 1. Sampling information, plant localization and its origin

\begin{tabular}{lccl}
\hline \multicolumn{1}{c}{ Species } & Symbol of plant collection & Plant number in plant collection & \multicolumn{1}{c}{ Origin } \\
\hline Cornus mas & AMUBGP & $191^{*}$ & No data \\
& AMUBGP & $1519^{*}$ & Planted before 1951 \\
AMUBGP & $7227^{*}$ & The Bolestraszyce Arboretum, Poland \\
KA & $49^{*}$ & Planted before 1926 \\
KA & $49^{*}$ & Planted before 1926 \\
DGPULS & No data & No data \\
DGPULS & No data & No data \\
\hline Cornus officinalis & RA & 5407 & Koshigaya Arboretum, Japan \\
& BGJUC & No data & Beijing Botanical Garden, China \\
& KA & $6956^{*}$ & Kyoto Botanical Garden, Japan \\
KA & $6956^{*}$ & Kyoto Botanical Garden, Japan \\
KA & $6956^{*}$ & Kyoto Botanical Garden, Japan \\
AMUBGP & $04987^{*}$ & Dresden, Germany \\
C. mas $\times$ C. officinalis & AMUBGP & $04987^{*}$ & Dresden, Germany \\
\hline
\end{tabular}

${ }^{1}$ AMUBGP: Adam Mickiewicz University Botanical Garden in Poznań; BGJUC: The Botanic Garden of The Jagiellonian University in Cracow; DGPULS: Dendrological Garden of University of Life Sciences in Poznań; KA: The Kórnik Arboretrum, RA: The Rogów Arboretum. *specimens examined genetically.

Table 2. The schedule of inflorescences, leaves, fruits and stones examined morphological and anatomical features

\begin{tabular}{ll}
\hline Plant organ & \multicolumn{1}{c}{ Feature } \\
\hline Leaf & $\begin{array}{l}\text { Petiole length; number of veins; occurrence/color } \\
\text { of hair tufts }\end{array}$ \\
Inflorescence & $\begin{array}{l}\text { Pedicel and bract length; number of flowers; differ- } \\
\text { ence between pedicel and bract length; pedicel } \\
\text { length/bract length ratio }\end{array}$ \\
& $\begin{array}{l}\text { Thickness of exocarp and mesocarp; stone length; } \\
\text { stone width; stone thickness; stone length/width } \\
\text { ratio; thickness of: endocarp, outer endocarp, in- } \\
\text { ner endocarp and transition sclereids (TS) zone; } \\
\text { number of cell layers in TS zone; locule number; } \\
\text { locule length; locule width; number of cavities in } \\
\text { endocarp; wall thickness percentage }{ }^{1} \text { (WTP); api- } \\
\text { cal cavity }\end{array}$ \\
\hline
\end{tabular}

${ }^{1}$ WTP is thickness of the valve (outer wall of endocarp) divided by the stone diameter $\times 100$.

cross and longitudinal sections with the use of Zeiss Axio Scope A1 and PZO sk14 light microscopes. Before sectioning the fruits had been stored in Formalin-Aceto-Alcohol (FAA), after which $50-70 \mu \mathrm{m}$ transverse and longitudinal sections were prepared using a Lietz manual sledge microtome.

\section{Genetic analysis}

Total genomic DNA was extracted from fresh, young leaves of individual plants, using a cetyl trimethylammonium bromide (CTAB) method (Doyle 1991) with minor modifications. Leaves were ground to a powder in liquid nitrogen using a mortar and pestle. The powdered tissue was mixed with a 1-2 ml extraction CTAB (cetyl trimethylammonium bromide) buffer with the addition of $3 \%$ polyvinyl- pyrrolidone (PVP) and $0.4 \% \beta$-mercaptoethanol. The mixture was then incubated at $65^{\circ} \mathrm{C}$ for 45 minutes. DNA was then extracted using a mixture of chloroform-octanol (octyl alcohol) (24:1). After centrifugation, DNA was recovered from the aqueous phase through precipitation with $96 \%$ ethanol, washed with $70 \%$ ethanol, air-dried, and resuspended in sterile water. The contaminating RNA was removed by digestion with RNase A. DNA quality and concentration was estimated by electrophoresis and spectrophotometry, adjusted to $20 \mathrm{ng} / \mu \mathrm{l}$ and used as a template in PCR reactions.

PCR RAPD amplification was performed in volumes of $16 \mu \mathrm{l}$ containing a double concentrated, ready-to-use PCR master mix (Fermentas), a 20 pM decamer primer, and $50 \mathrm{ng}$ of template DNA. For preliminary selection of the most informative RAPD primers for the species studied, 72 decanucleotide primers from commercially available primer kits A, B, $\mathrm{E}$, and $\mathrm{H}$ (Operon Technologies Inc., USA) were probed. The bulked segregant analysis (BSA) technique (Michelmore et al. 1991) was used to identify RAPD markers differentiating between both species and their putative hybrid. Chosen this way, 24 primers that resulted in polymorphic bands unique to each parent were used in further reactions with all examined species. DNA amplification reactions were performed in a thermocycler (M.J. Research, Inc.) programmed for 40 cycles divided into two stages differing in terms of annealing temperature. The first $20 \mathrm{cy}-$ cles were preceded by an initial denaturation at $95^{\circ} \mathrm{C}$ for 300 seconds; each cycle was composed of a denaturation step at $92^{\circ} \mathrm{C}$ for 90 seconds, an annealing step at $35^{\circ} \mathrm{C}$ for 90 seconds, and an extension step at 
$72^{\circ} \mathrm{C}$ for 120 seconds, after which, in order to enhance specificity, the annealing temperature was increased to $38^{\circ} \mathrm{C}$ and another 20 cycles followed, in which the other stages remained unchanged. The reaction was completed by final synthesis at $72^{\circ} \mathrm{C}$ for 300 seconds and storage at $4^{\circ} \mathrm{C}$ until turned off.

Part of the amplified products, for control of reaction, were separated in the presence of size markers by electrophoresis in $1.5 \%$ agarose gels in a $1 \times \mathrm{TBE}$ (Tris Borate/EDTA) buffer containing ethidium bromide. DNA bands were photographed under ultra violet light using the photo documentation system GBOX (Syngen Biotech). Selected reactions were then further separated in $6 \%$ polyacrylamide gels in $0.5 \times$ TBE buffer, and the results were visualized as above.

\section{Statistical analysis}

Data obtained from the biometric measurement were submitted to one-factor analysis of variance (ANOVA) in order to examine differences in means among the species studied. If critical differences were noted, multiple comparisons were carried out based on Duncan's test $(\mathrm{p}=0.05)$.

The obtained genetic profiles (fingerprints) were analyzed in terms of polymorphic RAPD markers that were unique to individual species and those that were common to one of the assumed parents and the potential hybrid. The percentage of polymorphic products indicating inheritance of traits from each of the species was calculated. All the profiles were compared according to the calculations given by Nei and Li (1979). Each polymorphic band was treated as a unit character and scored as a binary code. A similarity matrix was constructed from binary data using the formula NL $=2 a /(b+c)$, where $a$ is the number of RAPD fragments shared by the two specimens, and $b$ and $c$ are the number of RAPD fragments in each of them. The genetic distance $(\mathrm{D}=1-\mathrm{NL})$ and the UPGMA program were used for cluster analysis and generation of a dendrogram, graphically determining interrelations between the analyzed taxa. Statistical analyses were performed, and the dendrogram was created using Statistica software (Statsoft Version 9). A genetic distances matrix was also used to perform analysis of molecular variance (AMOVA) and to compute the distribution of genetic variability among and within groups of parental Cornus species. Significance levels for variance component estimates were computed using 9999 permutations (Irzykowska et al. 2012). AMOVA was performed using GenAlEx 6.41 (Peakall and Smouse, 2006).

The specimens and the seed material were deposited in the herbarium of the Botany Department (POZNB) of Poznań University of Life Sciences, Poland.

\section{Results}

Leaves of Cornus mas and C. officinalis bear three to five and six or seven lateral veins, respectively. An average number of six pairs of veins found on the leaves of the probable hybrid C. mas $\times$ C. officinalis showed its greater similarity to $C$. officinalis. The same result was found concerning to the presence of conspicuous tufts of dense brown hair in the axils of the lateral veins on the undersurface of the leaves, which is typical for C. officinalis. On the undersurface of C. mas leaves, inconspicuous tufts of white hair in the axils of the veins were present. The average length of the petioles of the examined dogwoods ranged from 7.3 to $8.13 \mathrm{~mm}$ but did not appear to be significantly different among the examined specimens (Table 3).

The average lengths of the bracts and pedicels of $C$. mas and C. officinalis examined specimens were found to have similar size ranges. The pedicels and bracts were shown to be significantly longer for $C$. mas and for the putative hybrid than for C. officinalis. The difference between the average pedicel and bract lengths showed that the pedicels were $1.05 \mathrm{~mm}$ longer than

Table 3. Ranges (minimum-maximum), mean values, SE, and coefficient of variation (CV) of inflorescence and leaf morphological features of the studied species

\begin{tabular}{lcccccccccccccccc}
\hline & \multicolumn{4}{c}{ Feature } & \multicolumn{4}{c}{ Cornus officinalis } & \multicolumn{1}{c}{ Cornus mas } & \multicolumn{4}{c}{ C. mas $\times$ C. officinalis } \\
\cline { 2 - 6 } & Min & Max & Mean & SE & CV & Min & Max & Mean & SE & CV & Min & Max & Mean & SE & CV \\
\hline Number of flowers & 15 & 32 & $24.00 \mathrm{a}$ & 4.12 & 0.17 & 14 & 38 & $25.00 \mathrm{a}$ & 6.10 & 0.24 & 14 & 37 & $25.80 \mathrm{a}$ & 5.44 & 0.21 \\
Pedicel length [mm] & 6.04 & 8.08 & $6.86 \mathrm{a}$ & 0.67 & 0.10 & 5.57 & 8.61 & $7.22 \mathrm{~b}$ & 0.96 & 0.13 & 7.33 & 10.75 & $9.11 \mathrm{~b}$ & 1.09 & 0.12 \\
Bract length [mm] & 5.17 & 6.58 & $5.81 \mathrm{a}$ & 0.43 & 0.07 & 4.95 & 7.76 & $6.95 \mathrm{~b}$ & 0.75 & 0.11 & 6.18 & 7.28 & $6.61 \mathrm{~b}$ & 0.27 & 0.04 \\
$\begin{array}{l}\text { Pedicel and bract length } \\
\text { difference [mm] }\end{array}$ & -0.25 & 1.93 & $1.05 \mathrm{a}$ & 0.60 & 0.57 & -0.72 & 1.02 & $0.27 \mathrm{a}$ & 0.56 & 2.07 & 0.61 & 3.85 & $2.50 \mathrm{~b}$ & 0.99 & 0.40 \\
$\begin{array}{l}\text { Pedicel length/bract } \\
\text { length ratio [mm] }\end{array}$ & 1.10 & 1.33 & $1.20 \mathrm{a}$ & 0.08 & 0.07 & 1.01 & 1.32 & $1.23 \mathrm{a}$ & 0.09 & 0.07 & 1.09 & 1.59 & $1.38 \mathrm{~b}$ & 0.15 & 0.11 \\
Number of veins & 5 & 8 & $6.07 \mathrm{~b}$ & 0.83 & 0.14 & 4 & 6 & $4.87 \mathrm{a}$ & 0.68 & 0.14 & 5 & 7 & $6.00 \mathrm{~b}$ & 0.79 & 0.13 \\
Petiole length [mm] & 5.40 & 9.75 & $8.13 \mathrm{a}$ & 1.13 & 0.14 & 4.60 & 11.45 & $7.88 \mathrm{a}$ & 1.99 & 0.25 & 3.00 & 10.00 & $7.37 \mathrm{a}$ & 1.59 & 0.22 \\
\hline
\end{tabular}

${ }^{1}$ Different letters denote significant differences by row at $p<0.05$ by Duncan's test. Same letters indicate a lack of statistically significant differences between analyzed species. 
the bracts for C. officinalis, $2.50 \mathrm{~mm}$ longer for the putative hybrid, and of similar length as the bracts for $C$. mas. The reciprocal ratio of pedicel/bract length did not differ significantly between C. mas and C. officinalis but it was significantly higher for the probable hybrid (Table 3).

The average number of locules found in drupes of C. officinalis and C. mas was 1.0 and 2.0, respectively. In the stones of the putative hybrid there was 1.23 locule in average. The obtained results concerning average stone length, width, and thickness showed that C. mas stones were significantly larger in comparison with $C$. officinalis and that the probable hybrid's stones were of a similar size as those obtained for $C$. officinalis (Table 4). The figures of the fruit sections indicate that the pericarp of the examined dogwoods consists of three well-developed layers: an exocarp, a fleshy mesocarp, and a stony endocarp. The exocarp is composed of a single-layer epidermis covered by a cuticle of moderate thickness, making the outlines of epidermal cells with a diameter of about $19 \mu \mathrm{m}$ visible. The mesocarp is composed of parenchymatous cells differing in diameter from approximately 25-55 $\mu \mathrm{m}$ to about $75-120 \mu \mathrm{m}$. The most outer part of the mesocarp is composed of one or two layers of hypodermal cells. They are slightly elongated tangentially and immediately subjacent to the epidermis (Fig. 1A). The fleshy mesocarp tissue lacks large intercellular spaces and remains rather compact even in fully ripened fruit. Eight main vascular bundles are located in a ring pattern in the mesocarp (Fig. 1B). They are called peripheral bundles, and four of them supply the stamen while the other four supply petals during flowering. At the apex of the fruit these bundles run very near to one another, forming a close series (Fig. 1C, D). In the mesocarp parenchyma, plenty of cells filled with anthocyanins and singular idioblasts with the large crystal bodies (druses) were observed, and the latter were often localized close to the vascular bundles (Fig. 1E). The endocarp of the examined cornelian cherries consists of two layers: the outer and the inner endocarp (Fig. 1F). The tissue composing the outer endocarp is formed by nearly isodiametric to slightly elongated rice-shaped sclereids with straight to smoothly curved cell walls or by fiber cells. Fibers are mainly oriented transversely and aligned around the walls of cavities present in the endocarp walls (Fig. 1F). On the longitudinal sections, the outer endocarp sclereids are slightly elongated tangentially (Fig. 1G). In the outer endocarp cells of both types dozens of tiny pits are present. On the outer margin of the endocarp, a narrow zone of two to five layers of cells is present. This part of the endocarp is formed of isodiametric sclereid-like cells with very delicate irregular wall thickenings and not many pits (Fig. 1H). Thickness of this zone ranged from $79.64 \mu \mathrm{m}$ for $C$. officinalis to $53.50 \mu \mathrm{m}$ for C. mas.
The thickness of this zone for the putative hybrid was intermediate $(40.59 \mu \mathrm{m})$ comparing to its parents, and did not differ significantly from that for C. mas. We have described the cells of this zone as the transition sclereids. They are easily distinguishable because the outer endocarp cells are much smaller than the mesocarp cells (Fig. 1H). According to our biometric measurements, thickness of the outer endocarp layer, measured across the germination valve, was greatest in C. mas $(1305.30 \mu \mathrm{m})$, least in C. officinallis (860.98 $\mu \mathrm{m})$, and intermediate in the putative hybrid $(1073.86 \mu \mathrm{m})$. These differences were significant (Table 4).

In the outer endocarp, two ventral bundles located at each end of the septum were present on the stone's transverse section (Fig. 2A). While the fruit and the stone are being formed, these bundles pass from the apex of the stone partway up the stone's surface and, in about one-third to one-half of its length, depending on the species, they enter the wall of the stone and continue underneath the surface (Fig. 2B, C). Figure 2 indicates that the described vascular bundles are accompanied by the transition sclereids (Fig. 2C).

The inner endocarp is composed of approximately six to nine layers of transversely elongated, interwoven fibers bounding the inner ovary wall. Its thickness was similar for all three examined taxa. Since they lie at right angles to the other cells of the stony pericarp, the boundary between the two is sharp (Fig. 1F). The inner endocarp marks the locule cavity in which the seed is surrounded by a single-layer testa. The testa is formed of square or rectangular cells with dimensions of 23.5-45.5 $\mu \mathrm{m}$ (Fig. 2D). The calculated wall thickness percentage (WTP) showed that, in the stones of $C$. officinalis and the putative hybrid, the participation of the germination valve in the whole stone thickness is significantly greater than in the stones of C. mas, despite the greater stone and endocarp average thicknesses found for that species (Table 4). The germination valve is surrounded by a few layers of isodiametric sclereids with rather thin, not much lignified walls looking similar to the transition cells. They facilitate further opening of the germination valve (Fig. 2E). The sclerenchyma cells comprising the stone's septa are isodiametric sclereids and somewhat elongated fibers of inner endocarp with plenty of pits (Fig. 2F). The septa and the endocarp walls of the fruit stone are riddled with cavities (Fig. 2E). They are rounded or ellipsoidal, $0.2-0.8 \mathrm{~mm}$ in diameter, and contain reddish, water-soluble substances. They form mostly a uniseriate cycle around each locule. The number of cavities in the endocarp wall was significantly lower for $C$. officinalis and for the putative hybrid than for $C$. mas, which might be the reason for the greater endocarp thickness in C. mas stones (Table 4). 


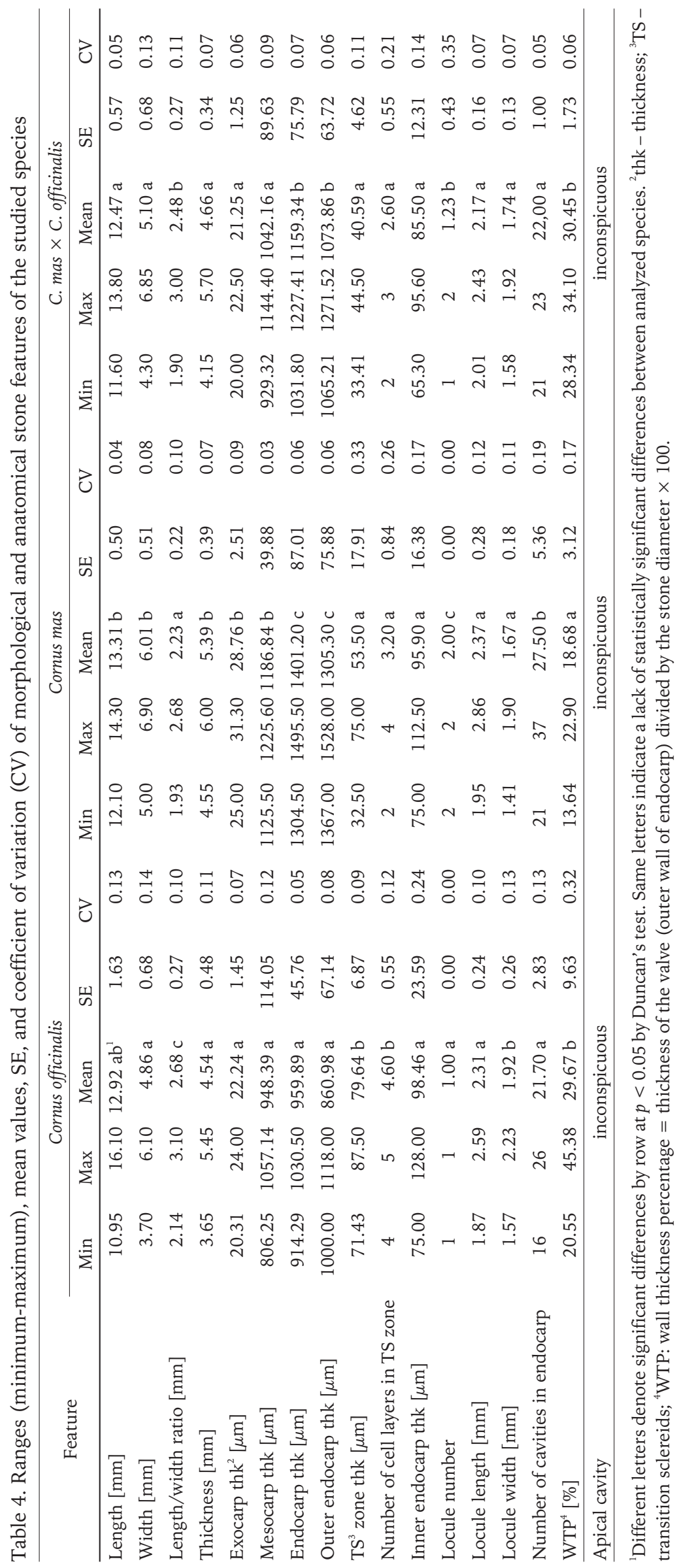



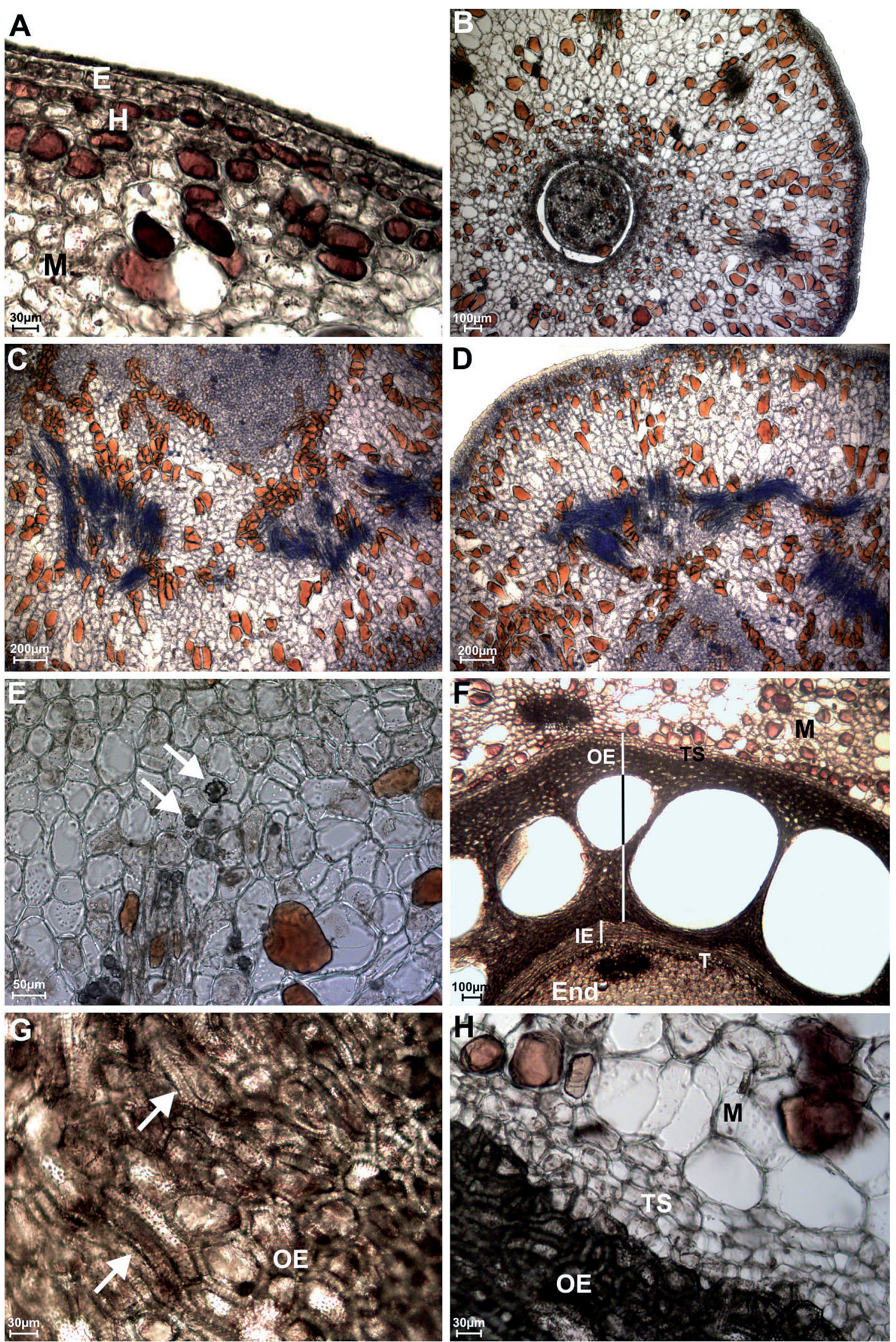

Fig. 1. Anatomical pericarp sections of Cornus mas, C. officinalis, and C. mas $\times$ C. officinalis showing: A. cross section, epidermis (E) and mesocarp (M) with one or two layers of hypodermis $(\mathrm{H})$; B. cross section, mesocarp with four main vascular bundles; C. cross section, series of main vascular bundles at about 1/10 of the fruit length; D. cross section, series of main vascular bundles at about 1/12 of the fruit length; E. cross section, druses present in mesocarp cells (arrows); F. cross section, mesocarp (M), transition sclereids (TS), outer endocarp (OE), inner endocarp (IE), testa (T), and endosperm (End); G. longitudinal section, tangentially elongated sclereids of outer endocarp with plenty of pits visible (arrows); H. cross section, transition sclereids of outer endocarp adjacent to mesocarp 

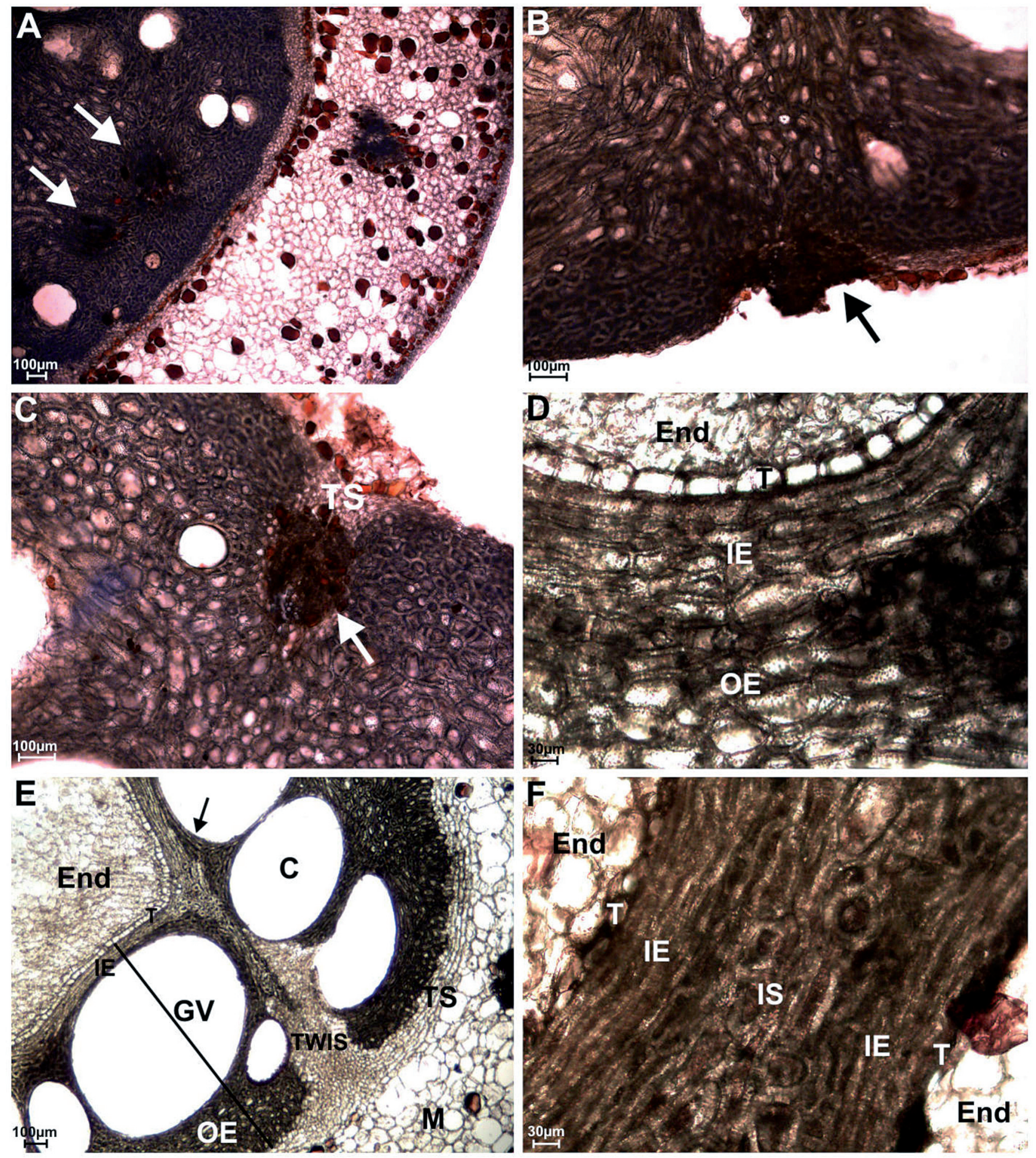

Fig. 2. Anatomical pericarp cross sections of Cornus mas and C. officinalis showing: A. two ventral bundles located at the end of the septum (arrows); B. ventral bundle (arrow) running on the stone surface, mesocarp removed; C. ventral bundle (arrow) accompanied by transition sclereids (TS) entering outer endocarp, mesocarp removed; D. outer endocarp (OE), inner endocarp (IE) around the locule, single-layer testa (T), and endosperm (End); E. mesocarp (M), endocarp structure with transition sclereids, outer endocarp, inner endocarp, cavities (C) surrounded by outer endocarp fibers, germination valve (GV) surrounded by thin-walled isodiametric sclereids (TWIS), and seed with testa and endosperm visible; F. stone septa composed of isodiametric sclereids (IS) and elongated fibers of inner endocarp with testa and endosperm of two seeds also visible 
Initial screening of bulks of C. mas and C. officinalis compared with their putative hybrid using 72 Operon decamer primers resulted in the identification of 24 primers that generated polymorphic DNA bands and bands present in only one of each parent species and hybrid, absent in other ones. An example of the DNA polymorphism patterns from primers OPH18, OPH20, OPB15, and OPA13 is presented in Figure 3. Twenty of the 24 RAPD fragments amplified by these primers were highly repeatable, enabling clear visualization on gels and unambiguous scoring of their presence or absence, and only these bands were taken
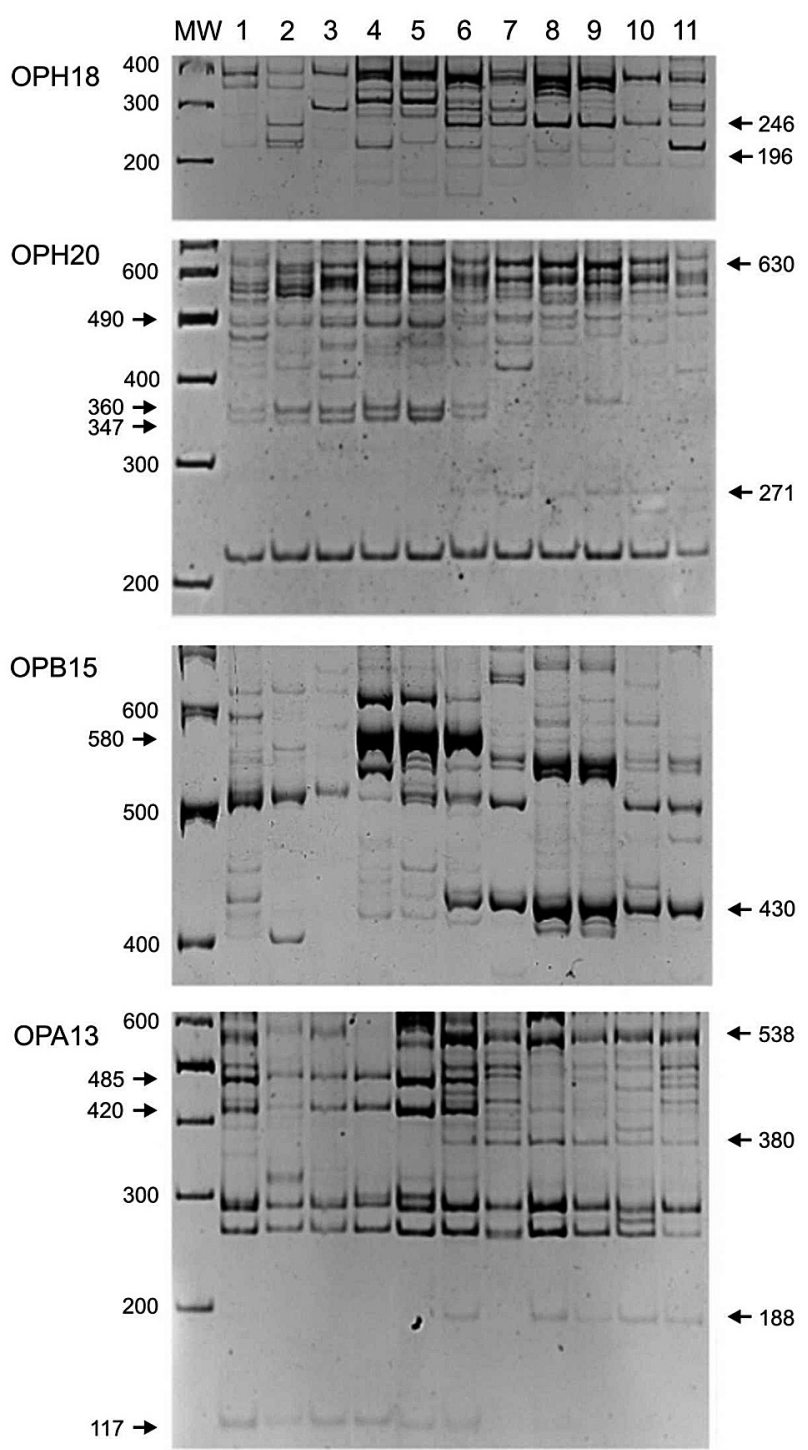

Fig. 3. Examples of electrophoregrams of RAPD products amplified on templates of 11 Cornus spp. accessions. Polymorphic products specific for hybrid and parents species are indicated by arrows. MW represents $100 \mathrm{bp}$ Fermentas molecular weight marker: 1-5, C. officinalis accessions; 6, C. mas $\times$ C. officinalis hybrid; 7-11, C. mas accessions. Cornelian cherries accessions 1-11 are described in Table 1 into account. Results of our analysis are summarized in Table 5.

The 20 primers selected from the 72 initial primers were used to evaluate the level of genetic diversity within the 11 accessions and phylogenetic linkages between the parental species and their putative hybrid. Amplification with chosen RAPD primers yielded a total of 485 fragments, of which 435 (89.7\%) were polymorphic. Eighty-two (18.8\%) of these polymorphic fragments were specific to Cornus mas, and 81 (18.6\%) were specific to Cornus officinalis. Complete $(100 \%)$ polymorphism was observed with primers OPB4, OPB8, OPB10, OPB15, OPH7, and OPH15. On average, one primer was amplified by 24 loci, and the size of the fragments ranged from 100 to $1300 \mathrm{bp}$ for all primers.

All of the analyzed C. mas profiles in comparison with the putative hybrid profile showed polymorphism with primers OPA $4_{466}$, OPA $10_{165,1220}$, OPA $13_{188,}$ $380,538,1150, \mathrm{OPA} 20_{576}, \mathrm{OPB1}_{220,1000}, \mathrm{OPB} 4_{680}, \mathrm{OPB6}_{260}$, $\mathrm{OPB}_{178}, \mathrm{OPB} 8_{740}, \mathrm{OPB} 11_{990}, \mathrm{OPB} 12_{400}, \mathrm{OPB} 15_{430}$, $\mathrm{OPH} 12_{148}, \mathrm{OPH}_{13}{ }_{253}, \mathrm{OPH}_{15} 5_{860}, \mathrm{OPH} 18_{196,246}$, and $\mathrm{OPH} 2 \mathrm{O}_{271,630}$. These polymorphic bands were not observed in the $C$. officinalis profile. The same situation was observed while comparing band patterns of $C$. officinalis and the probable hybrid plant. The markers OPA $4_{435}$, OPA $13_{117,420,485}$, OPA $20_{410}$, OPB $1_{345,460}$, $\mathrm{OPB}_{590}, 1000,1200, \mathrm{OPB}_{380}, \mathrm{OPB} 11_{375}, \mathrm{OPB} 15_{580}$, $\mathrm{OPB} 18_{325,450}, \mathrm{OPH} 7_{170,}, 185, \mathrm{OPH} 12_{232}, \mathrm{OPH} 13_{233}$, $\mathrm{OPH}_{15} 5_{505}$, and $\mathrm{OPH} 2 \mathrm{O}_{347,360,490}$ were observed in $\mathrm{C}$. officinalis and the probable hybrid but not in the C. mas pattern. Additionally, in the obtained profiles of the putative hybrid, specific products were observed (17 fragments $=3.9 \%$ of all polymorphic bands) that were absent in the profiles of both parents.

Eighteen out of 20 primers provided the diverse band profiles distinctly indicating the hybrid character of the C. mas $\times$ C. officinalis specimen. No significant differences were observed in the number of amplified products in individual species. Differences were observed rather in their distribution, making it possible to report the presence both of bands unique to each species and held in common between the hybrid and one of the parents (Fig. 3). In the case of $C$. mas $\times$ C. officinalis, 47 out of $170(27.6 \%)$ products comprised bands found in one of the parents: 23 (13.5\%) common with C. officinalis and 24 (14.1\%) with C. mas. At the same time, 17 (10\%) products unique to the hybrid were found. Thus, the performed analysis confirmed the hybrid character and intermediate morphological features of the examined plant.

In order to verify the phylogenetic relationships between the analyzed taxa, all of the polymorphic products were counted, and the percentage of the common products between them was compared. On the basis of the created datasheet, a matrix was estab- 
Table 5. Primers, their sequences, the number of resulting RAPD markers, fragment size and ratio of polymorphism in \% for each primer as a results of experiments performed among Cornus accessions

\begin{tabular}{|c|c|c|c|c|c|c|c|c|c|}
\hline Primer & Sequence $5^{\prime}-3^{\prime}$ & Size (bp) & $\begin{array}{l}\text { Monomorphic } \\
\text { bands }\end{array}$ & $\begin{array}{c}\text { Polymorphic } \\
\text { bands }\end{array}$ & $\begin{array}{c}\text { Unique for } C \text {. } \\
\text { mas/hybrid }\end{array}$ & $\begin{array}{c}\text { Unique for } \\
\text { C. off./hybrid }\end{array}$ & $\begin{array}{l}\text { Unique for } \\
\text { C. } m \times \text { C.off. }\end{array}$ & $\begin{array}{r}\text { Total } \\
\text { bands }\end{array}$ & $\begin{array}{r}\text { Ratio (\%) of } \\
\text { polymorphism }\end{array}$ \\
\hline OPA4 & AATCGGGCTG & $200-1300$ & 2 & 35 & 1 & 1 & 1 & 37 & 94.59 \\
\hline OPA10 & GTGATCGCAG & $150-1200$ & 15 & 5 & 2 & 0 & 0 & 20 & 25.00 \\
\hline OPA13 & CAGCACCCAC & $117-1200$ & 2 & 25 & 4 & 3 & 0 & 27 & 92.60 \\
\hline OPA20 & GTTGCGATCC & $200-1000$ & 2 & 23 & 1 & 1 & 0 & 25 & 92.00 \\
\hline OPB1 & GTTTCGCTCC & $150-1200$ & 2 & 23 & 2 & 2 & 2 & 25 & 92.00 \\
\hline OPB4 & GGACTGGAGT & $150-1300$ & 0 & 22 & 1 & 3 & 2 & 22 & 100.00 \\
\hline OPB6 & TGCTCTGCCC & $200-1000$ & 8 & 14 & 1 & 1 & 1 & 22 & 63.60 \\
\hline OPB7 & GGTGACGCAG & $150-1100$ & 2 & 24 & 1 & 0 & 2 & 26 & 92.30 \\
\hline OPB8 & GTCCACACGG & $150-1200$ & 0 & 29 & 1 & 0 & 0 & 29 & 100.00 \\
\hline OPB10 & CTGCTGGGAC & $200-1200$ & 0 & 22 & 0 & 0 & 1 & 22 & 100.00 \\
\hline OPB11 & GTAGACCCGT & $300-1200$ & 1 & 19 & 1 & 1 & 1 & 20 & 95.00 \\
\hline OPB12 & CCTTGACGCA & $200-1200$ & 1 & 14 & 1 & 0 & 2 & 15 & 93.30 \\
\hline OPB15 & GGAGGGTGTT & $200-1000$ & 0 & 25 & 1 & 1 & 0 & 25 & 100.00 \\
\hline OPB18 & CCACAGCAGT & $150-1200$ & 3 & 33 & 0 & 2 & 1 & 36 & 91.60 \\
\hline OPH7 & CTGCATCGTG & $140-1200$ & 0 & 20 & 0 & 2 & 1 & 20 & 100.00 \\
\hline OPH12 & ACGCGCATGT & $140-1000$ & 2 & 16 & 1 & 1 & 0 & 18 & 88.80 \\
\hline OPH13 & GACGCCACAC & $180-1250$ & 1 & 20 & 1 & 1 & 1 & 21 & 95.20 \\
\hline OPH15 & AATGGCGCAG & $150-1000$ & 0 & 25 & 1 & 1 & 1 & 25 & 100.00 \\
\hline OPH18 & GAATCGGCCA & $150-1100$ & 2 & 27 & 2 & 0 & 1 & 29 & 93.10 \\
\hline OPH20 & GGGAGACATC & $200-1000$ & 7 & 14 & 2 & 3 & 0 & 21 & 66.70 \\
\hline Total & & $117-1300$ & 50 & 435 & 24 & 23 & 17 & 485 & 89.70 \\
\hline
\end{tabular}

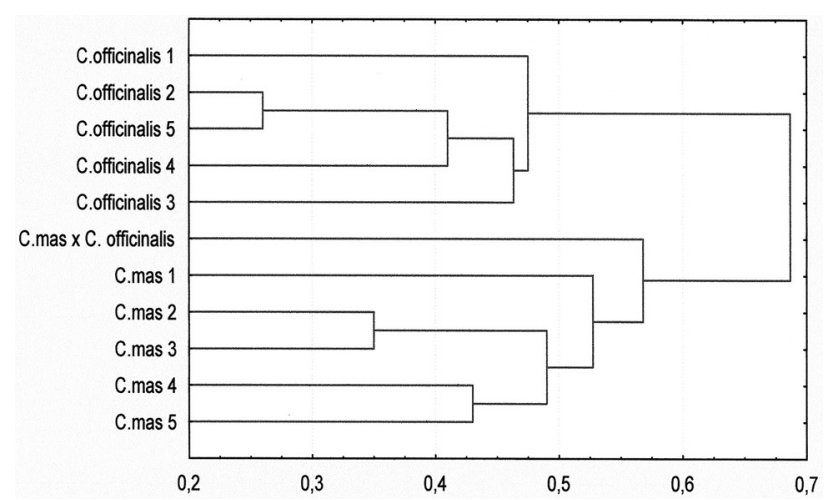

Fig. 4. Unweighted Pair Group Method with Arithmetic Mean (UPGMA) dendrogram of cluster groupings of the 11 studied genotypes of cornelian cherries based on 20 random RAPD primers and showing the genetic distance between species studied

lished for the genetic distance, and a dendrogram was plotted. The phylogenetic tree revealed two separate clusters representing C. mas and C. officinalis accessions, respectively. The highest genetic distance value was observed for C. mas $\times$ C. officinalis, although it belongs to the $C$. mas group (Fig. 4). The dendrogram confirmed previous assumptions from genetic profiles analysis that $C$. mas $\times C$. officinalis specimen is genetically closer to $C$. mas than to $C$. officinalis. Genetic differentiation between 11 analysed accessions was highlighted by analysis of molecular variance
Table 6. Analysis of molecular variance (AMOVA) based on 435 RAPD amplification products

\begin{tabular}{cccccc}
\hline $\begin{array}{c}\text { Source of } \\
\text { variation }\end{array}$ & d.f. & $\begin{array}{c}\text { Sum of } \\
\text { squares }\end{array}$ & $\begin{array}{c}\text { Mean } \\
\text { squares }\end{array}$ & $\begin{array}{c}\text { Estimated } \\
\text { variance }\end{array}$ & $\%$ \\
\hline $\begin{array}{c}\text { Among } \\
\text { groups }\end{array}$ & 1 & 217.8 & 217.8 & 30.7 & 32.0 \\
$\begin{array}{l}\text { Within } \\
\text { groups }\end{array}$ & 8 & 514.4 & 64.3 & 64.3 & 68.0 \\
Total & 9 & 732.2 & & 95.0 & \\
\hline
\end{tabular}

(AMOVA) which showed that $32 \%$ of total variation was attributed to between-group of parental Cornus species. The significant differentiation $\left(F_{S T}=0.323\right.$; $P=0.030$ ) between them was further supported by results of this analysis, showing that both the intraand the inter-group variability were found to be significant, with $32.0 \%$ of the genetic variance contributed by the differentiation between groups, whereas $68.0 \%$ was partitioned into intra-groups (Table 6).

Discussion

The diagnostic characteristics differentiating the two species under study, C. mas and C. officinalis, are connected with the morphology of leaves and inflorescences. They concern mainly the number of veins and the color of hair tufts present on the undersurface of leaves, as well as some flower features such as bracts and petiole size. All of the examined specimens of C. mas and C. officinalis had the appearance match- 
ing the taxonomic descriptions of the particular species (Seneta 1994), while only one specimen, described in our experiment as the putative hybrid between C. mas and C. officinalis, had an intermediate appearance. Our results concerning the average number of veins on C. mas and C. officinalis leaves are in agreement with other taxonomic descriptions (Xiang et al. 2003; Xiang et al. 2005; Xiang and Boufford 2005). Results concerning pedicel and bract lengths proved that pedicels of $C$. officinalis are much longer than bracts comparing with $C$. mas. However, we did not confirm the 2:1 pedicel/bract length ratio between $C$. officinalis and C. mas reported by Seneta (1994). According to Xiang et al. (2003), pedicels of the newly described cornelian cherry from China, C. eydenana, are of $8-12 \mathrm{~mm}$ in length, which is similar to the examined taxa, but that species is easily distinguished from the other cornelian cherries because of its evergreen habit, three or four secondary leaf veins, long peduculate inflorescences bearing 50-70 flowers, and larger fruits.

Fruits of cornelian cherries are drupes with longitudinally grooved stones. Drupes of C. mas are usually bilocular, having two ovules, while fruits of $C$. officinalis have a unilocular stone. Dogwood stones open by subapical, adaxial, elongated valves at the time of germination (Croquist 1981; Eyde 1987, 1988; Takahashi et. al. 2002; APG II 2003). The average locule number found in our study of drupes of $C$. mas and C. officinalis is in agreement with other findings (Murrell 1993; Manchester et al. 2010). Intermediate number of locules found in the stones of the putative hybrid specimen points for its cross-bred character. The described cornelian cherries pericarp structure is similar to other drupe fruits of the genus Prunus s.l. and the drupelet of Rubus sp. (Rosaceae) (Tukey and Young 1939; Sterling 1953, Reeve 1954a, 1954b; Zieliński et al. 2010). The shape of sclereids forming the outer endocarp layer is typical for the subg. Cornus (Manchester et al. 2010). Cross sections of endocarp revealed the presence of the specific sclereid-like cells with the cell walls much less thickened that it is in regular sclereids. According to Reeve (1954b) such cells forming distinct zone on the outer margin of the endocarp can be described as transition sclereids. According to Tukey and Young (1939), the line of demarcation between that portion of the pericarp which is destined to become stony and that which is to remain fleshy is discernible even at the beginning of fruit development because the cells of the former are smaller than those of the latter. According to the same authors, the cells of the stony pericarp remain relatively smaller into maturity, and this was confirmed in our study.

Outer layer of endocarp was characterized by the presence of the two ventral bundles located at each end of the septum. According to Wilkinson (1944), these ventral bundles separate centripetally from each of the two opposite main stamen bundles rather high in the ovary. Each of these bundles is composed of a ventral trace of one carpel and the adjacent trace of the second carpel, and it enters the ovule in the region of the funiculus. In C. mas, as in C. florida, the ovular traces are very heavy (Wilkinson 1944; Eyde 1988). Another very typical feature for Cornus, subg. Cornus species is the presence of subglobose cavities within the stone wall and septum. That is the diagnostic feature for these group of dogwoods (Murrell 1993; Manchester et al. 2010). Our results showing that the number of cavities in the endocarp of the putative hybrid fruits was significantly lower in comparison with C. mas, but not differing from C. officinalis proved its closer similarity to that species. Results obtained from the evaluation of genetic relationships between examined taxa based on random amplified polymorphic DNA (RAPD) markers demonstrated a high level of polymorphism among the examined cornelian cherries accesions, which is in agreement with earlier analysis of diversity among Cornus mas in Turkey by Ercisli et al. (2008). The partitioning of the genetic variation observed in groups of Cornus species, obtained by RAPD markers was $68 \%$ within groups and $32 \%$ among them. The $F_{S T}$ value of 0.323 revealed by RAPD data indicated relatively high levels of genetic differentiation between groups studied. On the base of them we have proved that the putative hybrid specimen with unclear taxonomic status is a hybrid between C. mas and C. officinalis.

In conclusion it was found out that few of the analyzed traits of the putative hybrid C. mas $\times$ C. officinalis, such as the pedicel and bract length difference, pedicel length/bract length ratio, the average number of locules in drupes, or the sclereid transition zone thickness, were significantly different from both of its parents, which may most probably indicate it's unclear taxonomic status. The results showing significantly longer pedicels and bracts of the hybrid in comparison with C. officinalis may prove its closer similarity to C. mas rather than to C. officinalis. On the other hand, several of the other examined morphological and anatomical features indicated that the hybrid species is more similar to $C$. officinalis than to C. mas. The obtained results related to the stone structure showed that the differences concerned mainly the thickness of its particular layers. We also showed that the hybrid specimen it genetically more similar to $C$. mas than to $C$. officinalis, even though results of our morphological and anatomical studies seem to indicate its greater similarity to C. officinalis. Differences in groupings based on molecular markers and those based on phenotypic traits have been described in strawberries (Garcia et al. 2002) and also reported in Cornus mas (Ercisli et al. 2008). Our results also indicate that DNA analysis using RAPD PCR as well as 
the ISSR method may be a good tool for DNA fingerprinting of different Cornus species and may also be used to identify their interspecific hybrids.

\section{Acknowledgments}

We would like to thank Ms. Ilona Wysakowska from Department of Botany, Poznań University of Life Sciences for her technical assistance in preparing anatomical sections and Mr. Jan Bocianowski from Department of Mathematical and Statistical Methods, Poznań University of Life Sciences for his assistance in performing statistical analysis.

\section{References}

APG II. 2003. An update of the Angiosperm Phylogeny Group classification for the orders and families of flowering plants: APG II. Botanical Journal of the Linnean Society 141: 399-436.

Benlloch R., Berbel A., Serrano-Mislata A., Madueno F. 2007. Floral initiation and inflorescence architecture: a comparative view. Annals of Botany 100: 659-676.

Croquist A. 1981. An integrated system of classification of flowering plants. Columbia University Press. New York.

Culpepper J.H., Sayavedra L.A., Bassam B.J. and Gresshoff P.M. 1991. Characterization of Cornus (Dogwood) Genotypes Using DNA Fingerprinting. Journal of the American Society for Horticultural Science 116: 1103-1107.

Doyle J. 1991. DNA protocols for plants-CTAB total DNA isolation. In: Hewitt GM, Johnston A (eds.). Molecular Techniques in Taxonomy. Springer, Berlin: 283-293.

Ercisli S., Orhan E., Esitken A., Yildrim N., Agar G. 2008. Relationships among some cornelian cherry genotypes (Cornus mas L.) based on RAPD analysis. Genetic Resources and Crop Evolution 55: 613-618.

Eyde R.H. 1987. The case for keeping Cornus in the broad Linnaean sense. Systematic Botany 12: 505-518.

Eyde R.H. 1988. Comprehending Cornus: Puzzles and Progress in the Systematics of the Dogwoods. The Botanical Review 54: 233-351.

Fan C., Xiang Q.-Y. 2001. Phylogenetic relationships within Cornus (Cornaceae) based on 26S rDNA sequences. American Journal of Botany 88: 1131-1138.

Fan C., Xiang Q.-Y. 2003. Phylogenetic analysis of Cornales based on 26S rDNA-matK-rbcL sequence data. American Journal of Botany 90: 1357-1372.

Feng Ch.-M., Xiang Q.-Y., Franks R.G. 2011. Phylogeny-based developmental analyses illuminate evolution of inflorescence architectures in dog- woods (Cornus s. 1., Cornaceae). New Phytologist 191: 850-869.

Garcia M.G., Ontivero M., Ricci J.C.D., Castagnaro A. 2002 Morphological traits and high resolution RAPD markers for identification of the main strawberry varieties cultivates in Argentina. Plant Breeding 121: 76-80.

Irzykowska L., Weber Z., Bocianowski J. 2012. Comparison of Claviceps purpurea populations originated from experimental plots or fields of rye. Central European Journal of Biology 7: 839-849.

Kehne C.L. 1978. The case of Dunbar Dogwood: A neglected Hybrid. Arnoldia 38: 50-54.

Manchester S.R., Xiang X.-P., Xiang Q.-Y. 2010. Fruits of cornelian cherries (Cornaceae: Cornus subg. Cornus) in the Paleocene and Eocene of the Northern Hemisphere. International Journal of Plant Sciences 171: 882-891.

Michelmore R.W., Paran I., Kessel R.V. 1991. Identification of markers linked to disease resistance genes by bulked segregant analysis: a rapid method to detect markers in specific genomic regions using segregating populations. Proceedings of the National Academy of Sciences of the USA 88: 9828-9832.

Murrell Z. 1993. Phylogenetic Relationships in Cornus (Cornaceae). Systematic Botany 18: 469-493.

Nei M., Li W.H. 1979. Mathematical model for studying genetic variation in terms of restriction endonucleases. Proceedings of the National Academy of Sciences of the USA 76: 5269-5273.

Orton E.R. 1985. Interspecific hybridization among Cornus florida, C. kousa, and C. nuttallii. Proceedings of the International Plant Propagator's Society 35: 655-661.

Peakall R., Smouse P.E. 2006. GENALEX 6: genetic analysis in Excel. Population genetic software for teaching and research. Molecular Ecology Notes 6: 288-295.

Reeve R.M. 1954a. Fruit histogenesis in Rubus strigosus. I. Outer epidermis, parenchyma, and receptacle. American Journal of Botany 41: 152-160.

Reeve R.M. 1954b. Fruit histogenesis in Rubus strigosus. II. Endocarp tissues. American Journal of Botany 41: 173-181.

Seneta W. 1994. Drzewa i krzewy liściaste C. Wydawnictwo Naukowe PWN. Warszawa: $168-196$.

Shi A., Kantartzi S., Mmbaga M., Chen P. 2010. Development of ISSR PCR markers for diversity study in dogwood (Cornus spp.). Agriculture and Biology Journal of North America 1: 189-194.

Sterling C. 1953. Developmental anatomy of the fruit of Prunus domestica L. Bulletin of the Torrey Botanical Club 80: 457-477. 
Takahashi M., Crane P.R., Manchester S.R. 2002. Hironoia fusiformis gen. et sp. nov.; a cornalean fruit from the Kamikitaba locality (Upper Cretaceous, Lower Coniacian) in northeastern Japan. Journal of Plant Research 115: 463-473.

Tukey H.B., Young J.O. 1939. Histological study of the developing fruit of the sour cherry. Botanical Gazette 100: 723-749.

Wadl P.A., Skinner J.A., Dunlap J.R., Reed S.M., Rinehart T.A., Pantalone V.R., Trigiano R.N. 2009. Honeybee-mediated controlled pollinations in Cornus florida and C. kousa Intra- and Interspecific Crosses. HortScience 44: 1527-1533.

Wagner W.H. Jr. 1990. A natural hybrid of gray dogwood, Cornus racemosa, and round-leaved dogwood, C. rugosa, from Michigan. The Michigan Botanist 29: 131-137.

Wilkinson A.M. 1944. Floral anatomy of some species of Cornus. Bulletin of the Torrey Botanical Club 71: 276-301.

Williams J.G.K., Kubelik A.R., Livak K.J., Rafalski J.A. and Tingey S.V. 1990. DNA polymorphism amplified by arbitrary primers are useful as genetic markers. Nucleic Acids Research 18: 6531-6535.

Xiang Q.-Y., Boufford D.E. 2005. Cornaceae. In: Flora of China 14: 206-221.

Xiang Q.-Y., Brunsfeld S. J., Soltis D.E., Soltis P.S. 1996. Phylogenetic relationship in Cornus based on chloroplast DNA restriction sites: implications for biogeography and character evolution. Systematic Botany 21: 515-534.
Xiang Q.-Y., Manchester S. R., Thomas D. T., Zhang W., Fan C. 2005. Phylogeny, biogeography, and molecular dating of cornelian cherries (Cornus, Cornaceae): tracking tertiary plant migration. Evolution 59: 1685-1700.

Xiang Q.-Y., Shui Y.-M., Murrel Z. 2003. Cornus eydeana (Cornaceae), A New Cornelian Cherry from China - Notes on Systematics and Evolution. Systematic Botany 28: 757-764.

Xiang Q.-Y., Soltis D.E., Morgan D.R., Soltis P.S. 1993. Phylogenetic relationships of Cornus L. sensu lato and putative relatives inferred from rbcL sequence data. Annals of the Missouri Botanical Garden 80: 723-734.

Xiang Q.-Y., Soltis D. E., Soltis P. S. 1998. Phylogenetic relationships of Cornaceae and close relatives inferred from matK and rbcL sequences. American Journal of Botany 85: 285-297.

Xiang Q.-Y., Thomas D.T., Zhang W., Manchester S.R., Murrell Z. 2006. Species level phylogeny of the genus Cornus (Cornaceae) based on molecular and morphological evidence - implications for taxonomy and Tertiary intercontinental migration. Taxon 55: 9-30.

Zieliński J., Guzicka M., Tomaszewski D., Maciejewska-Rutkowska I. 2010. Pericarp anatomy of wild roses (Rosa L., Rosaceae). Flora 205: 363-369.

Zietkiewicz E., Rafalski A., Labuda D. 1994. Genome fingerprinting by simple sequence repeat (SSR) anchored polymerase chain reaction amplification. Genomics 20: 176-183. 